\title{
DOES EMPLOYER BRANDING AFFECT JOB EMBEDDEDNESS? THE MEDIATING ROLE OF DEDICATION AND PERCEIVED ORGANIZATIONAL SUPPORT ${ }^{1}$
}

\author{
Berivan TATAR ${ }^{2}$ \\ Büşra MÜCELDİLỉ ${ }^{3}$ \\ Oya ERDİL ${ }^{3}$
}

\author{
Received Date (Başvuru Tarihi): 01/11/2018 \\ Accepted Date (Kabul Tarihi): 15/11/2018 \\ Published Date (Yayın Tarihi): 30/11/2018
}

\begin{abstract}
Along with emerging the war for talent, scholars have given ample attention to employer branding concept referring the a whole of values and benefits that organizations provide for both attracting and retaining the best possible talent. In this context, the purpose of this study is to investigate the effect of employer branding on the favorable employee behavior as job embeddedness via the mediating role of the dedication and perceived organizational support. Data collected from 200 respondents have been analyzed through Structural Equation Modeling. As a result of analyses, the hypothesized model was supported. Findings of the study revealed that employer branding has effect the dedication, job embeddedness and organizational support perception of employees. Additionally, dedication and perceived organizational support partially mediate the relationship between employer branding and job embeddedness. Finally, the theoretical and practical implication, limitations of the study and suggestions for future research are discussed.
\end{abstract}

Keywords: Employer Branding, Job Embeddedness, Perceived Organizational Support

JEL Codes: M51, M12, L2

\section{ISSVEREN MARKASI İŞE GÖMÜLMÜŞLÜĞÜ ETKILLER Mİ? ADANMIŞLIK VE ALGILANAN ÖRGÜTSEL DESTEĞİN ARACILIK ROLÜ}

\section{ÖZ}

Yetenekler savaşının baş göstermesiyle birlikte araştırmacılar, organizasyonların mümkün olan en iyi yetenekleri cezbetmek ve elde tutmak için sağladığı tüm değer ve faydaları ifade eden işveren markası kavramına büyük ilgi göstermiştir. Bu bağlamda bu çalışmanın amacı; adanmışlık ve algılanan örgütsel desteğin aracılık rolü ışı̆̆ında, işveren markasının işe gömülmüşlük davranışı üzerindeki olumlu etkilerini araştırmaktır. 200 katılımcıdan toplanan veriler, yapısal eşitlik modellemesi ile analiz edilmiştir. Analizler sonucunda, önerilen araştırma modeli desteklenmiştir. Sonuçlar, işveren markasının, çalışanların adanmışlık, örgütsel destek algısı ve işe gömülmüşlük düzeylerini etkilediğini ortaya koymuştur. Buna ek olarak, adanmışlık ve algllanan örgütsel destek, işveren markası ve iş gömülmüşlük arasındaki ilişkiye kısmen aracılık etmektedir. Son olarak, teorik ve pratik uygulama, çalışmanın sınırlamaları ve gelecekteki araştırmalara yönelik öneriler tartışılmıştır.

Anahtar Sözcükler: İşveren Markası, Işe Gömülmüşlük, Algılanan Örgütsel Destek

JEL Kodlart: M51, M12, L2

\footnotetext{
${ }^{1}$ Bu çalışma "Business and Organization Research Conference-BOR 2018" adlı kongrede yayınlanmıştır.

${ }^{2}$ Res. Assist., Gebze Technical University, btatar@gtu.edu.tr

https://orcid.org/0000-0002-0934-3734

${ }^{3}$ Assist. Prof. Dr., Gebze Technical University, bmuceldili@gtu.edu.tr

${ }^{3}$ Prof. Dr., Gebze Technical University, erdil@ gtu.edu.tr

https://orcid.org/0000-0003-2770-6137

https://orcid.org/0000-0003-3793-001X
} 


\section{INTRODUCTION}

Human resource has become more vital in today's business world due to the fact that talent scarcity is now felt more than past decades. In demographic side, many employees are beginning to retire and leaving of these experienced workforce has created the gap in labor market (Unit, 2008) and organizations have faced difficulty in replacing them with new talented employees. According to the results of the Talent Shortages Survey (Manpower Group, 2018) conducted in 2018 on 39,195 employers from 43 regions and countries, $45 \%$ of employers have difficulty in filling the gap in open positions and this result has increased by 5\% compared to 2016 and is the highest percentage experienced since 2006. Besides, Japan is one of the countries facing the most difficulties (89\%) and Turkey has ranked sixthly among the countries with the most difficulty in filling open positions (66\%). Main reasons for facing this difficulty are lack of applicants, the necessary experience and required hard skills.

Additionally, it is expected that 38 million or 40 million potential shortage of college-educated workers will be experienced in 2020 while the number of older people excluded to global labor force could reach 360 million by 2030 (Dobbs et al., 2012). This will foster the impact of already existing scarcity of talented and experienced employees. On the other hand, peoples' attitudes towards the work have been changed and they generally tend to consider their career development and look for the organizations contributing their skills, career growth and marketability instead of being committed to one firm for an extended period of time (Collins and Kanar, 2014).

These difficulties in finding, attracting and retaining the best talents intensify the efforts of organizations to develop effective strategies. Employer branding has emerged as one of these strategies used for overcoming talent shortages. The term, employer branding refers to the "strategy a company could use to differentiate its brand as an employer from those of their competitors, with the purpose of ensuring good applicants, and maintaining talent within the organization" (Gehrels and De Looij, 2011:45). Through the benefits different from the competitors, organizations create and promise the unique work experience to align with the expectations of both potential and current employees. This experience brings together the attraction and retention of competent employees by creating the perception of a great place to work.

Despite a vast number of studies from a variety of disciplines, employer branding should be conceptualized, defined and investigated. Edwards (2010) noted that "the literature on employment branding is in its relative infancy within the HR academic field" and "there are a number of key areas of research from the organizational behavior arena" (p. 19). Additionally, the impact of employer branding on the employees' outcomes and behavior has remained unclear (Backhaus and Tikoo 2004). 
Moreover, recent studies have generally focused employer branding on the potential employees' side, there is a scarcity of studies from the point of current employees (Maxwell and Knox, 2009: Lievens et al. (2007).

For this, the study fills an important gap in management literature by reviewing the extant literature on perceived employer branding and reflects an understanding of employer branding from the perspective of existing employees in Turkey and also demonstrates the mediating role of dedication and perceived organizational support.

\section{LITERATURE REVIEW AND HYPOTHESES}

\subsection{Employer Branding}

The concept of employer branding has been developed by combining the marketing and human resources field with the aim of reducing the effects of the war for talent. The term, employer branding, firstly introduced by the Ambler and Barrow (1996) and defined as "the package of functional, economic, and psychological benefits provided by employment, and identified with the employing company" (p. 188). In this context organizations, as an employer, create the perception of a great place to work with a variety of benefits promised in return for being a member of current organizations. Backhaus and Tikoo (2004) put emphasis on the target market of organizations with the employer branding and defined this groups as the firm's current and potential employees. Similarly, Conference Board (2001: 3) argued that employer branding “encompasses the firm's value system, policies, and behaviors toward the objectives of attracting, motivating, and retaining the firm's current and potential employees." Based on this definition, employer branding is the whole of value provided to both potential and current employees with aim of attracting and retaining them.

As a process, employer branding includes the three main steps which are developing employee value proposition, external and internal marketing of the employer branding for creating awareness in the target group. For the first step, organizations primarily need to define the value proposition including the aforementioned values package similar to the customer-oriented view (Mosley, 2007). Employee value proposition refers to "the value or benefits an employee perceives by serving as a member of the organization" (Heger, 2007: 121). These values and benefits provided in employee value proposition classified in the literature in different ways as functional, economic and psychological benefits (Ambler and Barrow, 1996); development, application, economic, social and interest value (Berthon, Ewing and Hah, 2005); caring, enabling, career growth, credible and fair, flexible and ethical, product and service brand image, positive employer image and global exposure (Srivastava and Bhatnagar, 2010). Organizations will be the attractive extent to which their employee 
value propositions are distinctive and promise unique work experience regardless of how these benefits classified in the value proposition of organization.

Moreover, external and internal marketing of the employee value proposition is another important issue for the employer brand management. The external marketing of employer branding focuses on attracting the right potential employees with being their first choice of employer (Backhaus and Tikoo, 2004) and mainly based on the employer image of the organizations. Similar to consumer's perspective of the image, potential employees have a perception a line with publicity, sponsorship activities, positive word of mouth endorsements and advertising about employer image of the organizations. These perceptions about potential employers shape their attitudes and beliefs, defined also as employer image, about the employment experience that they may experience (Collins and Stevens, 2002). Beside, employer image strongly affects their intention and behavior of applying to organizations (Cable and Turban, 2001). For example, perception about that organization having a good social environment and interaction in the organization and good reputation increase the attractiveness of the employer brand (Schlager et al., 2011). Additionally, candidates perceive as more attractive the organizations having a sense of social responsibility, considering empowerment of employees in their organizational process and having overall compensation packages (Agrawal and Swaroop, 2009). innovativeness and competence attributes of employers also lead potential employees to apply for the job (Lievens and Highhouse, 2003).

For the internal marketing of the employer branding; consistency, clarity, credibility, and investment made for employer branding activities have determined the effectiveness of the employer branding (Wilden, Gudergan and Lings, 2010). Through sharing the value proposition differentiated from the competitors and providing unique work experience, employees tend to adopt to the organization and develop a sense of ownership (Backhaus and Tikoo, 2004). As a result, they intend to stay in the organization (Ambler and Barrow, 1996). In this regard, organizations have recently focused on integrating the externally promised and internally experienced value proposition for attractiveness (Mosley, 2007).

Besides attracting and retaining the best-talented people, employer branding is a crucial concept because of improving the organizational performance, engagement and creating competitive advantage through differentiation organizations from their competitors (Fernon, 2008). Being a member of organizations having a strong employer brand also enhance employee satisfaction (Davies, 2008) and commitment (Ito, Brotheridge and McFarland, 2013).

As a result, employer branding is a crucial and complex concept for the organization and require extensive evaluation in planning as well as implementing a phase of a complement of activities (Gaddam, 2008). In particular, employer branding should be differentiated from the promises of the 
competitors, attractive for luring both potential and existing talent, and consistent in terms of promised and experienced employer branding (Backhaus and Tikoo 2004).

\subsection{Employer Branding and Perceived Organizational Support}

From the social exchange perspective (Blau, 1964), employees tend to feel an obligation for showing extra effort, working hard and performing better their job as a return for the activities of organization considering their employees' interests, caring for their well-being and contributing their development. One of this exchange relationship is called as perceived organizational support delineating the exchange relationship between employees and the organization (Wayne, Shore and Liden, 1997). It is stubborn fact that, of all organizational activities, human resources practices of organizations have also shaped the effectiveness of this exchange relationship. Organizations investing in their human capital through human resource management practices and valuing them for their contribution have been perceived as supportive by their employees. As a result, this sense of support leads to a long-lived mutual relationship between employers and employees of the organizations (Allen, Shore and Griffeth, 2003).

Specifically, Wayne et al. (1997) showed that developmental experiences of employees influence the perception of organizational support. Similarly, training opportunities also have made important contributions to sense of organizational support (Ahmad and Bakar, 2003; Hemdi, 2009) and career development programs have been identified as a type of organizational support perceived by employees (Foong-ming, 2008). Examined in terms of economic value presented in the context of employer brand, in the literature, it is seen that the presence of the pay and satisfaction from the pay level, promotion opportunities (Foong-ming, 2008; Wayne et al., 1997) and existence of performance appraisal system and reward given by the organization in the literature affects the sense of support (Gavino, Wayne and Erdogan, 2012).

From the viewpoint of social value aspect of employer brand, Gavino et al. (2012) stated that participation to decision making has a strong effect on organizational support. Besides, supervisory support also proves to the perception of the support (Foong-ming, 2008). Information flow and sharing through informing about organizational activities as well as asking opinions of the employees contribute to building support in the organization (Tremblay et al., 2010). Therefore, the following hypothesis is offered:

$H_{1}$ : Employer branding is positively related to perceived organizational support.

\subsection{Perceived Organizational Support and Job Embeddedness}

Providing a variety of benefits, caring for the well-being of employees, attributing the value to their contribution, giving the opportunity to access information contributes to the perception of 
organizational support. Fulfillment of these needs of employees enhances their attention for the welfare of the organization (Eisenberger et al., 2001) and they tend to reciprocate with higher affective commitment, job satisfaction, the positive mood at work, desire to remain with the organization (Rhoades and Eisenberger, 2002). This higher desire to remain in the organization may lead employees to be more embedded to their job. Indeed, in their study about tourism sector, Akgunduz and Sanli (2017) stated that hotel managers create a feeling of support through both considering employees' suggestions and complaints and including them to decision making process. In this way, organizations can create a highly embedded workforce in the organization. Hence, we formulated our hypothesis:

\section{$H_{2}$ : Perceived organizational support is positively related to job embeddedness.}

\subsection{Employer Branding and Job Embeddedness}

Employer branding is a crucial concept for the development of favorable employees' attitudes (Schlager, Bodderas, Maas and Luc Cachelin, 2011). Job embeddedness is one of these attitudes of employees desired by the organizations because of showing the reasons and motivations behind the employees' decision of remain or leave from the organizations (Bergiel, Nguyen, Clenney and Stephen Taylor, 2009).

The studies conducted in this field revealed that human resource practices increased the fit, link and sacrifice dimensions of embeddedness. For example, the existence of growth opportunities and development for the knowledge, skills, and abilities of the employees increase their fit perception. Offering unique, hard to imitate and differentiated benefits make difficult to sacrifice this working environment (Ghosh and Gurunathan, 2015). Besides, social environment, support of both supervisors and colleagues and participating in the decision making links employees with the organizations (Hom et al, 2009). Tian, Cordery and Gamble (2016) examined human resource practices with regard of ability-motivation-opportunity framework and demonstrated that ability-enhancing human resource management (HRM) practices as training and development, motivation-enhancing HRM practices through rewarding their effort and performance, opportunity-enhancing HRM practices through flexibility and job autonomy in doing their job generate higher link, fit perception and being unable to sacrifice. Bambacas and Kulik (2013) investigated the role of employee development opportunities through professional growth and professional interaction dimensions and found that organizations' practices for contributing the development of the employees lead employees to be more embedded through sacrifice dimension to their job. Bergiel et. al. (2009) noted that compensation packages, supervisor support, and growth opportunity are related to embeddedness. Besides, the values given and provided to the employees through training opportunities, pay, and promotions, social facilities, recognition, and appreciation may improve their perceptions that they are supported by their 
organizations, and this perception of support may increase the embeddedness of employees to work. Based on these earlier findings, we propose that:

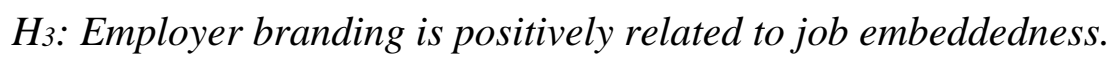

$H_{4}$ : Perceived organizational support mediates the relationship between employer branding and job embeddedness.

\subsection{Employer Brand and Dedication}

Davies, Mete and Whelan (2017) argued that the effect of employer branding, on the employee engagement has not been examined adequately in the literature. Besides, Davies, Mete and Whelan (2017) investigated employer brand image through personality dimensions as warmth and competence and found that this aspect of employer brand image influences the engagement of employees. Nazari and Ahadi (2016) demonstrated that employer branding leads employees to engage with their organization. Additionally, Piyachat, Chanongkorn and Panisa (2014) reported a positive relationship between employer branding and engagement and development and interest value are the most important predictors of the employee engagement followed by organizations' reputation, economic value and employment aspects of employer branding. With this regard, it has been expected that dedication which is one of the aspects of work engagement is predicted by the employer branding. Finally, we construct the following hypothesis:

$H_{5}$ : Employer branding is positively related to dedication.

\subsection{Dedication and Job Embeddedness}

Work engagement is the work-related concept defining as a combination of high energy and identification of employees (Schaufeli \& Bakker, 2004) and in several studies, it is revealed that work engagement has important role yielding positive outcomes. Job embeddedness is one of this desired outcomes of the employees. In other words, engagement is the equivalent of the employee's reason to stay in the organization, which is at the center of the concept of embeddedness. According to Bakker et al. (2007) resources offering to employees for meeting the job demand lead them to be more engaged. Highly engaged employees feel attached to the organization and, as a result, higher engagement level attends being more embedded and connected to their job (Tabak and Hendy, 2016). Karatepe and Wheeler (2008) stated that work engagement level of employees affects the embeddedness of them. Because employees having higher identification and engagement tend to link more them with the organization, fit their values with the organizational goals and values and not sacrifice easily because of opportunities and benefits provided by the organization. Additionally, dedication may have an important role in the relationship between employer branding and job embeddedness. In return for the opportunities and benefits provided through employer branding, 
employees may tend to dedicate to their organization and, as a result, enhance their embeddedness. Accordingly, we construct the following hypotheses:

H6: Dedication is positively related to job embeddedness.

H7: Dedication mediates the relationship between employer branding and job embeddedness.

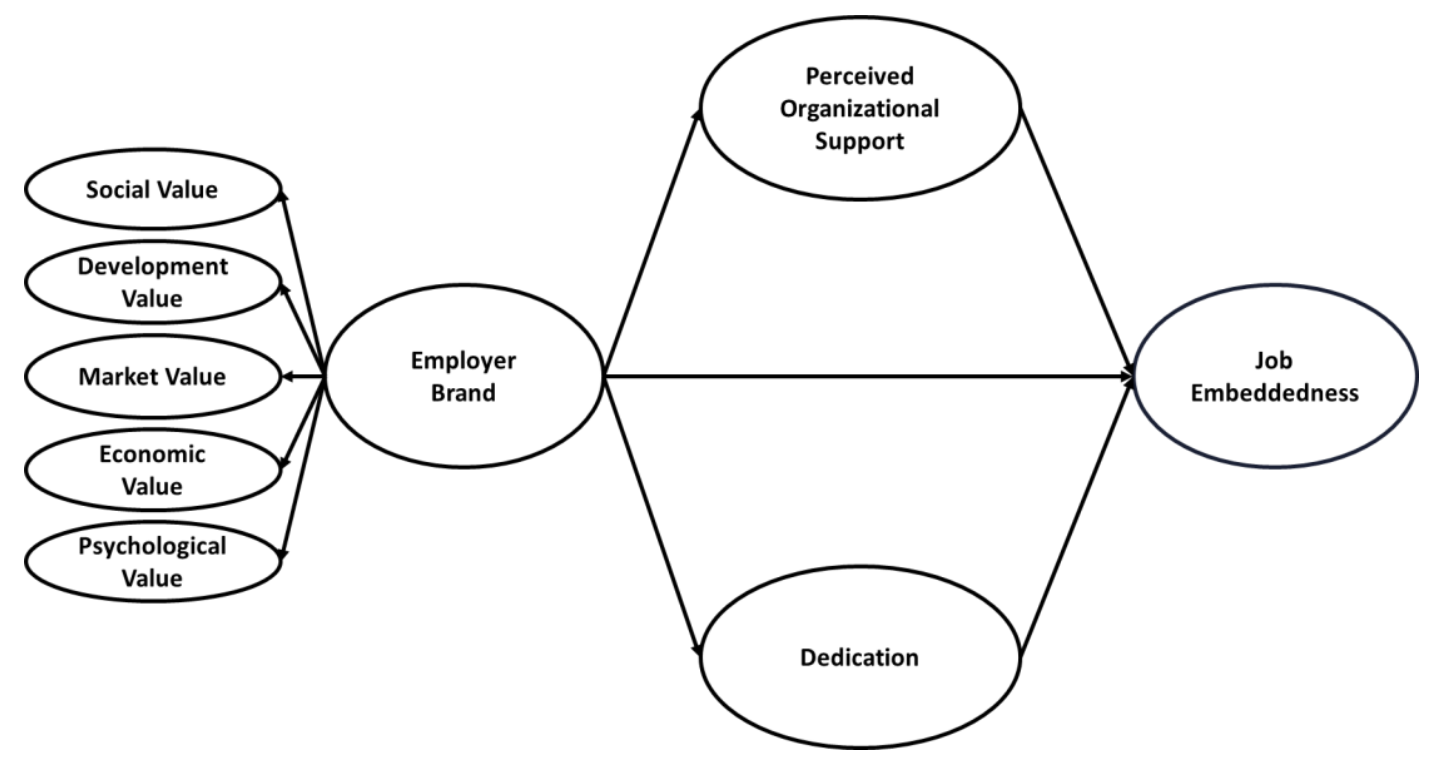

Figure 1. Conceptual Research Model

\section{RESEARCH METHOD}

\subsection{Sample and Data Collection}

The questionnaire method has been used for data collection. The questionnaire has consisted of two parts and 45 items including questions for determining both the demographic characteristics of the participants and the participants' perception of employer branding and organizational support, their dedication and job embeddedness. Items were scored five-point Likert-type scale from strongly disagree (1) to strongly agree (5).

The study was carried out on 200 respondents working in different sectors. $57.5 \%$ of the respondents were male and $42.5 \%$ were female. In terms of educational distribution, $0.5 \%$ had a high school degree, $42.5 \%$ of the participants had a university degree, $39.5 \%$ had a master degree and $17.5 \%$ had a doctoral degree. Besides, $26 \%$ of the participants were a 22-29 age group, 53\% were a 30-37 age group, $16 \%$ were $38-45$ age group and 5\% were 46 and above. Average work experience was 6-10 years.

\subsection{Measures}

Employer branding was measured using a 25-item scale developed by Berthon et al. (2005) was used to determine the employer branding perception level of current employees. Sample items are "The 
organization both values and make use of your creativity" and "An attractive overall compensation package".

Perceived organizational support was measured using the eight-item short form of scale developed by Lynch, Eisenberger and Armeli (1999). Sample items are "My organization cares about my opinions." and "My organization is willing to help me if I need a special favor."

Job embeddedness was measured using the seven-item scale developed by Crossley et al. (2007). Sample items are "I feel attached to this organization." and "It would be difficult for me to leave this organization."

Dedication was measured using the five-item dedication subscale of the Utrecht Work Engagement Scale (Schaufeli et al., 2002). Sample items are "I am proud on the work that I do" and "My job inspires me".

\section{ANALYSIS}

\subsection{Factor and Reliability Analysis}

Confirmatory Factor Analysis has been performed for determining the factor structure of the study variables through the AMOS software package (see in Table 1). According to results for the assessment of measurement model, our model has demonstrated an acceptable fit $\left(\chi^{2}(561)=1140.679\right.$ $\left.\mathrm{CFI}=0.908 \mathrm{IFI}=0.909 \mathrm{TLI}=0.897 \chi^{2} / \mathrm{df}=2.033 \mathrm{RMSEA}=0.072\right)$. In the analysis, 9 items have been eliminated because of lower and cross loading. Finally, employer brand consists of the five-factor structure as a social value, development value, market value, economic value, and psychological value while dedication, perceived organizational support and job embeddedness have a single factor structure. Factor loadings are between .54 and .91 .

Table 1. Results of Factor and Reliability Analysis

\begin{tabular}{|l|c|c|c|c|c|}
\hline & $\begin{array}{c}\text { Number } \\
\text { of Items }\end{array}$ & $\begin{array}{c}\text { Factor } \\
\text { Loadings }\end{array}$ & $\begin{array}{c}\text { Cronbach's } \\
\boldsymbol{\alpha}\end{array}$ & CR & AVE \\
\hline Social Value & 5 & $.70-.88$ & .90 & .89 & .68 \\
\hline Development Value & 4 & $.75-.84$ & .88 & .88 & .65 \\
\hline Market Value & 3 & $.69-.83$ & .81 & .82 & .60 \\
\hline Economic Value & 2 & $.83-.89$ & .85 & .85 & .74 \\
\hline Psychological Value & 3 & $.57-.83$ & .72 & .73 & .48 \\
\hline Dedication & 5 & $.76-.83$ & .91 & .90 & .65 \\
\hline Perceived Organizational Support & 8 & $.74-.87$ & .94 & .94 & .74 \\
\hline Job Embeddedness & 6 & $.74-.91$ & .94 & .94 & .67 \\
\hline
\end{tabular}

For the reliability analysis, Cronbach's Alpha and Composite Reliability were reported and values of all variables for both Cronbach's Alpha and Composite Reliability were above .70 defined as criterion value (Nunnally and Bernstein, 1994). In terms of validity, AVE scores of approximately all variables exceed the .50 criterion for the convergent validity (Fornell and Larcker, 1981) with the 
exception of psychological value. On the other hand, for the discriminant validity, the square root of average variance explained for each variable the square root of the AVE in each factor is greater than the correlations between the variable pairs and satisfied the discriminant validity (Fornell and Larcker, 1981).

Mean and standard deviation related to the variables in the research model and the correlations between the variables has been shown in Table 2 .

Table 2. Means, Standard Deviations, and Correlations Among The Variables

\begin{tabular}{|c|c|c|c|c|c|c|c|c|c|c|}
\hline Variables & Mean & S.D. & SV & DV & MV & $\mathbf{E V}$ & PV & DED & POS & JE \\
\hline SV & 3.98 & 0.73 & $(\mathbf{0 . 8 2})$ & & & & & & & \\
\hline DV & 3.88 & 0.78 & $0.56^{* *}$ & $(\mathbf{0 . 8 0})$ & & & & & & \\
\hline MV & 3.99 & 0.77 & $0.48^{* * *}$ & $0.64^{* *}$ & (0.77) & & & & & \\
\hline EV & 3.55 & 0.91 & $0.49^{* * *}$ & $0.58^{* *}$ & $0.58^{* *}$ & $(\mathbf{0 . 8 6})$ & & & & \\
\hline PV & 3.92 & 0.71 & $0.60^{* *}$ & $0.62^{* *}$ & $0.54^{* *}$ & $0.48^{* * *}$ & (0.69) & & & \\
\hline DED & 4.10 & 0.74 & $0.58^{* * *}$ & $0.74^{* *}$ & $0.58^{* *}$ & $0.42^{* *}$ & $0.61^{* *}$ & $(0.81)$ & & \\
\hline POS & 3.68 & 0.77 & $0.60^{* *}$ & $0.76^{* *}$ & $0.59^{* *}$ & $0.61^{* *}$ & $0.69^{* *}$ & $0.61^{* *}$ & $(0.81)$ & \\
\hline JE & 3.73 & 0.81 & $0.51^{* *}$ & $0.64^{* *}$ & $0.55^{* *}$ & $0.61^{* *}$ & $0.62^{* *}$ & $0.61^{* *}$ & $0.68^{* *}$ & (0.86) \\
\hline
\end{tabular}

As seen in Table 2, there are significant relationships between the variables forming the research model. According to these findings, all aspects of employer branding has a significant impact on the dedication, perceived organizational support and job embeddedness. Additionally, dedication and perceived organizational support have a positive significant impact on the job embeddedness.

\subsection{Hypotheses Testing}

Mediating role of dedication and perceived organizational support in relationship between employer brand and job embeddedness has been analyzed, based on the approach of Baron and Kenny (1986), with PROCESS macro for SPSS through using 5000 bootstrapping which is stated as adequate for gathering reasonably accurate confidence interval estimates (Hayes, 2009) and Sobel Test (Sobel, 1982). Findings related to mediating test have been given in Table 3 and Table 4. 
Table 3. Result of Mediating Analysis for Perceived Organizational Support

\begin{tabular}{|c|c|c|c|c|c|c|}
\hline Independent Var. & Dep. Var. & $\mathbf{R}^{2}$ & $\mathbf{F}$ & $\beta$ & $\mathbf{t}$ & $\mathbf{p}$ \\
\hline Social Value & \multirow{5}{*}{$\begin{array}{c}\text { Perceived } \\
\text { Organizational } \\
\text { Support }\end{array}$} & 0.36 & 113.530 & 0.63 & 10.655 & .000 \\
\hline Development Value & & 0.57 & 272.220 & 0.75 & 16.499 & .000 \\
\hline Market Value & & 0.34 & 105.706 & 0.59 & 10.281 & .000 \\
\hline Economic Value & & 0.37 & 117.273 & 0.51 & 10.829 & .000 \\
\hline Psychological Value & & 0.48 & 187.303 & 0.75 & 13.685 & .000 \\
\hline Perceived Organizational Support & $\begin{array}{c}\text { Job } \\
\text { Embeddedness }\end{array}$ & 0.46 & 174.960 & 0.68 & 13.227 & .000 \\
\hline \multicolumn{7}{|l|}{ Model 1} \\
\hline Social Value & \multirow{3}{*}{$\begin{array}{c}\text { Job } \\
\text { Embeddedness }\end{array}$} & 0.26 & 70.616 & 0.56 & 8.403 & .000 \\
\hline Social Value & & \multirow{2}{*}{0.48} & \multirow{2}{*}{92.618} & 0.17 & 2.434 & .015 \\
\hline Perceived Organizational Support & & & & 0.61 & 9.206 & .000 \\
\hline \multicolumn{7}{|l|}{ Model 2} \\
\hline Development Value & \multirow{3}{*}{$\begin{array}{c}\text { Job } \\
\text { Embeddedness }\end{array}$} & 0.42 & 144.252 & 0.67 & 12.010 & .000 \\
\hline Development Value & & \multirow{2}{*}{0.50} & \multirow{2}{*}{101.732} & 0.31 & 3.949 & .000 \\
\hline Perceived Organizational Support & & & & 0.47 & 5.888 & .000 \\
\hline \multicolumn{7}{|l|}{ Model 3} \\
\hline Market Value & \multirow{3}{*}{$\begin{array}{c}\text { Job } \\
\text { Embeddedness }\end{array}$} & 0.30 & 85.782 & 0.58 & 9.261 & .000 \\
\hline Market Value & & \multirow{2}{*}{0.50} & \multirow{2}{*}{99.166} & 0.23 & 3.588 & .000 \\
\hline Perceived Organizational Support & & & & 0.58 & 8.878 & .000 \\
\hline \multicolumn{7}{|l|}{ Model 4} \\
\hline Economic Value & \multirow{3}{*}{$\begin{array}{c}\text { Job } \\
\text { Embeddedness }\end{array}$} & 0.38 & 121.463 & 0.55 & 11.021 & .000 \\
\hline Economic Value & & \multirow{2}{*}{0.53} & \multirow{2}{*}{112.012} & 0.28 & 5.149 & .000 \\
\hline Perceived Organizational Support & & & & 0.51 & 7.996 & .000 \\
\hline \multicolumn{7}{|l|}{ Model 5} \\
\hline Psychological Value & \multirow{3}{*}{$\begin{array}{c}\text { Job } \\
\text { Embeddedness }\end{array}$} & 0.39 & 126.701 & 0.71 & 11.256 & .000 \\
\hline Psychological Value & & \multirow{2}{*}{0.51} & \multirow{2}{*}{103.028} & 0.32 & 4.120 & .000 \\
\hline Perceived Organizational Support & & & & 0.50 & 6.984 & .000 \\
\hline
\end{tabular}

In the first stage of the mediating test, the relationship between the dimensions of employer brand as an independent variable and perceived organizational support as a dependent has been examined. In the first step of this phase, social value $(\beta=.63, p<.001)$, development value $(\beta=.75, p$ $<.001)$, market value $(\beta=.59, \mathrm{p}<.001)$, economic value $(\beta=.51, \mathrm{p}<.001)$ and psychological value $(\beta$ $=.75, \mathrm{p}<.001)$ have significantly affected perceived organizational support, supporting H1. In the second step, the effect of the perceived organizational support $(\beta=.68, p<.001)$ on the job embeddedness were found, supporting $\mathrm{H} 2$. Additionally, social value $(\beta=.56, \mathrm{p}<.001)$, development value $(\beta=.67, \mathrm{p}<.001)$, market value $(\beta=.58, \mathrm{p}<.001)$, economic value $(\beta=.55, \mathrm{p}<.001)$ and psychological value $(\beta=.71, \mathrm{p}<.001)$ have significantly affected job embeddedness, supporting $\mathrm{H} 3$. In the last step of the analysis, dimensions of employer brand and perceived organizational support were analyzed together and the effects of these variables on the job embeddedness were examined with aim of investigating the mediation effect. As a result, findings showed that the relationship between employer brand and job embeddedness is still significant, but the effect level of social value $(\beta=.17$, $\mathrm{p}<.05)$, development value $(\beta=.31, \mathrm{p}<.001)$, market value $(\beta=.23, \mathrm{p}<.001)$, economic value $(\beta=$ $.28, \mathrm{p}<.001)$ and psychological value $(\beta=.32, \mathrm{p}<.001)$ reduced with adding perceived organizational 
support to regression. Finally, the Sobel test has been confirmed to verify the mediating effect; the result confirmed the existence of the mediating effect of perceived organizational support in the relationship between social value $(Z=5.85 \mathrm{p}=.000)$, development value $(Z=3.73 \mathrm{p}=.000)$, market value $(Z=5.63 \mathrm{p}=.000)$, economic value $(Z=5.11 \mathrm{p}=.000)$, psychological value $(Z=5.06 \mathrm{p}=.000)$ and job embeddedness, supporting $\mathrm{H} 4$.

Table 4. Result of Mediating Analysis for Dedication

\begin{tabular}{|c|c|c|c|c|c|c|}
\hline Independent Var. & Dependent Var. & $\mathbf{R}^{2}$ & $\mathbf{F}$ & $\boldsymbol{\beta}$ & $\mathbf{t}$ & $\mathbf{p}$ \\
\hline Social Value & \multirow{5}{*}{ Dedication } & 0.34 & 104.906 & 0.59 & 10.242 & .000 \\
\hline Development Value & & 0.55 & 245.078 & 0.70 & 15.655 & .000 \\
\hline Market Value & & 0.34 & 104.895 & 0.56 & 10.241 & .000 \\
\hline Economic Value & & 0.18 & 44.714 & 0.34 & 6.686 & .000 \\
\hline Psychological Value & & 0.37 & 121.141 & 0.63 & 11.006 & .000 \\
\hline Dedication & Job Embeddedness & 0.38 & 121.997 & 0.61 & 11.045 & .000 \\
\hline \multicolumn{7}{|l|}{ Model 1} \\
\hline Social Value & \multirow{3}{*}{ Job Embeddedness } & 0.26 & 70.616 & 0.56 & 8.403 & .000 \\
\hline Social Value & & \multirow{2}{*}{0.41} & \multirow{2}{*}{69.982} & 0.25 & 3.391 & .000 \\
\hline Dedication & & & & 0.52 & 7.168 & .000 \\
\hline \multicolumn{7}{|l|}{ Model 2} \\
\hline Development Value & \multirow{3}{*}{ Job Embeddedness } & 0.42 & 144.252 & 0.67 & 12.010 & .000 \\
\hline Development Value & & \multirow{2}{*}{0.46} & \multirow{2}{*}{84.595} & 0.44 & 5.439 & .000 \\
\hline Dedication & & & & 0.33 & 3,853 & .000 \\
\hline \multicolumn{7}{|l|}{ Model 3} \\
\hline Market Value & \multirow{3}{*}{ Job Embeddedness } & 0.30 & 85.782 & 0.58 & 9.261 & .000 \\
\hline Market Value & & \multirow{2}{*}{0.43} & \multirow{2}{*}{75.657} & 0.30 & 4.303 & .000 \\
\hline Dedication & & & & 0.49 & 6.784 & .000 \\
\hline \multicolumn{7}{|l|}{ Model 4} \\
\hline Economic Value & \multirow{3}{*}{ Job Embeddedness } & 0.38 & 121.463 & 0.55 & 11.021 & .000 \\
\hline Economic Value & & \multirow{2}{*}{0.53} & \multirow{2}{*}{112.320} & 0.38 & 7.993 & .000 \\
\hline Dedication & & & & 0.47 & 8.020 & .000 \\
\hline \multicolumn{7}{|l|}{ Model 5} \\
\hline Psychological Value & \multirow{3}{*}{ Job Embeddedness } & 0.39 & 126.701 & 0.71 & 11.256 & .000 \\
\hline Psychological Value & & \multirow{2}{*}{0.47} & \multirow{2}{*}{89.982} & 0.44 & 6.020 & .000 \\
\hline Dedication & & & & 0.41 & 5.733 & .000 \\
\hline
\end{tabular}

According to Table 4 , social value $(\beta=.59, \mathrm{p}<.001)$, development value $(\beta=.70, \mathrm{p}<.001)$, market value $(\beta=.56, p<.001)$, economic value $(\beta=.34, p<.001)$ and psychological value $(\beta=.63$, $\mathrm{p}<.001$ ) have significantly affected dedication, supporting H5. In the second step, the effect of the dedication $(\beta=.61, \mathrm{p}<.001)$ on the job embeddedness were found, supporting H6. In the last step of the analysis, dimensions of employer brand and perceived organizational support were analyzed together and the effects of these variables on the job embeddedness were examined with aim of investigating the mediation effect. As a result, findings showed that the relationship between employer brand and job embeddedness is still significant, but the effect level of social value $(\beta=.25, p<.001)$, development value $(\beta=.44, \mathrm{p}<.001)$, market value $(\beta=.30, \mathrm{p}<.001)$, economic value $(\beta=.38, \mathrm{p}$ $<.001)$ and psychological value $(\beta=.44, \mathrm{p}<.001)$ reduced with adding perceived organizational 
support to regression. Finally, the Sobel test has been confirmed to verify the mediating effect; the result confirmed the existence of the mediating effect of perceived organizational support in the relationship between social value $(Z=6.94 \mathrm{p}=.000)$, development value $(Z=5.53 \mathrm{p}=.000)$, market value $(Z=6.70 \mathrm{p}=.000)$, economic value $(\mathrm{Z}=6.41 \mathrm{p}=.000)$, psychological value $(\mathrm{Z}=6.20 \mathrm{p}=.000)$ and job embeddedness, supporting $\mathrm{H} 7$.

\section{DISCUSSION}

The main purpose of the study is to explore the role of employer branding in the development of desired employees' attitudes as dedication, perceived organizational support and job embeddedness. The study also aims to contribute literature based on the need of further studies for determining the effect of employer brand on existing workers (Backhaus and Tikoo 2004; Maxwell and Knox, 2009; Lievens et al., 2007), development of the studies in the field of engagement and determine its predictors (Bakker, Schaufeli, Leiter and Taris, 2008), increasing the limited studs about the role of human resources on the embeddedness (Bambacas and Kulik, 2013).

Firstly, results showed that development and psychological value has impact on the dedication, job embeddedness and perceived organizational support. In the same vein, Lievens and Highhouse (2003) noted that symbolic (psychological) traits refer to the intangible and subjective attributes of employer branding that employees need these traits for maintaining their self-identity and self-image. Additionally, the traits relatively more decisive than the instrumental traits in shaping the attractiveness perception of the employees for the banking sector. Lievens et al. (2005) also revealed that symbolic attributes provide differentiation rather than instrumental traits for the Army's employer attractiveness.

Contrary to the study of Eisenberger, Rhoades and Cameron (1999) asserted that payment in the organization has no impact on the perceived organizational support, our findings revealed that promotions as well as payment effects the organizational support perception. Similar to findings of Wayne, Shore and Liden (1997), our study found that developmental activities through employer branding also improve the sense of organizational support.

This study also contributes literature with delineating the relationship between employer branding and dedication aspect of the work engagement as a response for call of Davies, Mete and Whelan (2017) to examine employer branding as an antecedent of engagement. Findings revealed that dedication of employees depends on the existence of development and psychological value. In a similar way, Gibbon (2006) asserted that emotional factors are more effective on engagement rather than other determinants such as payment.

From the point of job embeddedness, results showed that all values provided as a part of employer branding have a positive impact on the job embeddedness. Bergiel et. al. (2009) stated that compensation and growth opportunity and supervisory support effect the embeddedness of employees 
while training has not. Contrarily, our study showed that development value including the training opportunities is related to embeddedness and also the greatest impact on the embeddedness. On the other hand, mediating role of dedication and perceived organizational support was examined and results showed that dedication and perceived organizational support partially mediates the relationship between aspects of employer branding and job embeddedness.

\subsection{Limitations and Future Research}

Within the scope of this study job embeddedness has been used as a unidimensional construct while job embeddedness can be investigated through different conceptualization. For instance, Mitchell et al. (2001) has defined embeddedness with three aspects as links, fit, and sacrifice. Analyzing the role of employer branding on these aspects of job embeddedness may provide more comprehensive results and viewpoint. In a similar vein, other dimensions of work engagement as vigor and absorption can be examined as a consequence of employer branding concept. In addition to mediating analysis, future research can investigate the potential moderating variables as gender, work experience, and psychological well-being. it would be better to focus on specific sectors or to compare the findings of different sectors instead of collecting data, as in this study, regardless of sector distinction. 


\section{REFERENCES}

Agrawal, R. K., \& Swaroop, P. (2009). Effect of employer brand image on application intentions of B-school undergraduates. Vision, 13(3), 41-49.

Ahmad, K. Z., \& Bakar, R. A. (2003). The association between training and organizational commitment among whitecollar workers in Malaysia. International journal of training and development, 7(3), 166-185.

Akgunduz, Y., \& Sanli, S. C. (2017). The effect of employee advocacy and perceived organizational support on job embeddedness and turnover intention in hotels. Journal of Hospitality and Tourism Management, 31, 118-125.

Allen, D. G., Shore, L. M., \& Griffeth, R. W. (2003). The role of perceived organizational support and supportive human resource practices in the turnover process. Journal of management, 29(1), 99-118.

Ambler, T., \& Barrow, S. (1996). The employer brand, Journal of Brand Management, vol. 4, no. 3, pp. 185-206.

Bakker, A. B., Hakanen, J. J., Demerouti, E., \& Xanthopoulou, D. (2007). Job resources boost work engagement, particularly when job demands are high. Journal of educational psychology, 99(2), 274.

Bakker, A. B., Schaufeli, W. B., Leiter, M. P., \& Taris, T. W. (2008). Work engagement: An emerging concept in occupational health psychology. Work \& Stress, 22(3), 187-200.

Bambacas, M., \& Kulik, T. C. (2013). Job embeddedness in China: How HR practices impact turnover intentions. The International Journal of Human Resource Management, 24(10), 1933-1952.

Backhaus, K. \& Tikoo, S. (2004), "Conceptualizing and researching employer branding”, Career development international, $9(5), 501-517$.

Bergiel, E. B., Nguyen, V. Q., Clenney, B. F., \& Stephen Taylor, G. (2009). Human resource practices, job embeddedness and intention to quit. Management Research News, 32(3), 205-219.

Berthon, P., Ewing, M., \& Hah, L. L. (2005). Captivating company: dimensions of attractiveness in employer branding. International journal of advertising,24(2), 151-172.

Blau, P. (2017). Exchange and power in social life. Routledge.

Cable, D. M., \& Turban, D. B. (2001). establishing the dimensions, sources, and value of job seekers' employer knowledge during recruitment. Research in personnel and human resources management, 20, 115-164.

Collins, C. J., \& Kanar, A. M. (2014). Employer brand equity and recruitment research. The Oxford handbook of recruitment, 284-297.

Collins, C. J., \& Stevens, C. K. (2002). The relationship between early recruitment-related activities and the application decisions of new labor-market entrants: a brand equity approach to recruitment. Journal of applied psychology, 87(6), 1121.

(The) Conference Board (2001), Engaging Employees through Your Brand, The Conference Board, New York, NY.

Crossley, C. D., Bennett, R. J., Jex, S. M., \& Burnfield, J. L. (2007). Development of a global measure of job embeddedness and integration into a traditional model of voluntary turnover. Journal of Applied Psychology, 92(4), 1031.

Davies, G. (2008). Employer branding and its influence on managers. European Journal of Marketing, 42(5/6), 667-681.

Davies, G., Mete, M., \& Whelan, S. (2018). When employer brand image aids employee satisfaction and engagement. Journal of Organizational Effectiveness: People and Performance, 5(1), 64-80.

Dobbs, R., Madgavkar, A., Barton, D., Labaye, E., Manyika, J., Roxburgh, C., ... \& Madhav, S. (2012). The world at work: Jobs, pay, and skills for 3.5 billion people (Vol. 28). Greater Los Angeles: McKinsey Global Institute.

Eisenberger, R., Huntington, R., Hutchison, S., \& Sowa, D. (1986). Perceived organizational support. Journal of Applied psychology, 71(3), 500.

Eisenberger, R., Rhoades, L., \& Cameron, J. (1999). Does pay for performance increase or decrease perceived selfdetermination and intrinsic motivation?. Journal of personality and social psychology, 77(5), 1026.

Eisenberger, R., Armeli, S., Rexwinkel, B., Lynch, P. D., \& Rhoades, L. (2001). Reciprocation of perceived organizational support. Journal of applied psychology, 86(1), 42.

Fernon, D. (2008). Maximising the power of the employer brand. Admap, 494, 49.

Foong-ming, T. (2008). Linking Career development practices to turnover intention: The mediator of perceived organizational support. Journal of Business and Public Affairs, 2(1), 1-16.

Fornell, C., \& Larcker, D. F. (1981). Evaluating structural equation models with unobservable variables and measurement error. Journal of Marketing Research, 18(1), 39-51.

Gaddam, S. (2008). Modeling Employer Branding Communication: The Softer Aspect of HR Marketing Management. ICFAI Journal of Soft Skills, 2(1).

Gavino, M. C., Wayne, S. J., \& Erdogan, B. (2012). Discretionary and transactional human resource practices and employee outcomes: The role of perceived organizational support. Human Resource Management, 51(5), 665-686.

Gehrels, S. A., \& de Looij, J. (2011). Employer branding: A new approach for the hospitality industry. Research in Hospitality Management, 1(1), 43-52.

Ghosh, D., \& Gurunathan, L. (2015). Do commitment based human resource practices influence job embeddedness and intention to quit?. IIMB Management Review, 27(4), 240-251.

Gibbons, J. M. (2006). Employee engagement: A review of current research and its implications. Conference Board. 
Heger, B. K. (2007). Linking the employment value proposition (EVP) to employee engagement and business outcomes: Preliminary findings from a linkage research pilot study. Organization Development Journal, 25(2), P121.

Hemdi, M. A. (2009). Investigating hotel employees' organizational commitment: The influence of human resource management practices and perceived organizational support. Journal of Tourism, Hospitality \& Culinary Arts, 1(3), 1-20.

Hom, P. W., Tsui, A. S., Wu, J. B., Lee, T. W., Zhang, A. Y., Fu, P. P., \& Li, L. (2009). Explaining employment relationships with social exchange and job embeddedness. Journal of Applied Psychology, 94(2), 277.

Karatepe, O. M., \& Ngeche, R. N. (2012). Does job embeddedness mediate the effect of work engagement on job outcomes? A study of hotel employees in Cameroon. Journal of Hospitality Marketing \& Management, 21(4), 440-461.

Lievens, F., \& Highhouse, S. (2003). The relation of instrumental and symbolic attributes to a company's attractiveness as an employer. Personnel Psychology, 56(1), 75-102.

Lynch, P. D., Eisenberger, R., \& Armeli, S. (1999). Perceived organizational support: Inferior versus superior performance by wary employees. Journal of applied psychology, 84(4), 467.

Manpower Group. (2018). Solving the Talent Shortage Build, Buy, Borrow and Bridge. https://go.manpowergroup.com/hubfs/TalentShortage\%202018\%20(Global)\%20Assets/PDFs/MG_TalentShorta ge2018 10\%206 25 18 FINAL.pdf?t=1538422203894

Mitchell, T. R., Holtom, B. C., Lee, T. W., Sablynski, C. J., \& Erez, M. (2001). Why people stay: Using job embeddedness to predict voluntary turnover. Academy of management journal, 44(6), 1102-1121.

Mosley, R. W. (2007). Customer experience, organisational culture and the employer brand. Journal of brand management, 15(2), 123-134.

Nazari, Y., \& Ahadi, R. (2016). The Mediating Role of Job Engagement in the Relationship Between the Employer Brand and Citizenship Behavior" Behrouz Skandarpour," Manouchehr Manteghi. International Business Management, $10(10), 1833-1841$.

Nunnally, J. C., \& Bernstein, I. H. (1994). Psychometric Theory (McGraw-Hill Series in Psychology) (Vol. 3). New York: McGraw-Hill.

Piyachat, B., Chanongkorn, K., \& Panisa, M. (2014). The Mediate Effect of Employee Engagement on the Relationship between Perceived Employer Branding and Discretionary Effort. DLSU Business \& Economics Review, 24(1).

Rhoades, L., \& Eisenberger, R. (2002). Perceived organizational support: a review of the literature. Journal of applied psychology, 87(4), 698.

Schaufeli, W. B., \& Bakker, A. B. (2004). Job demands, job resources, and their relationship with burnout and engagement: A multi-sample study. Journal of Organizational Behavior, 25, 293-315.

Schaufeli, W. B., Salanova, M., González-Romá, V., \& Bakker, A. B. (2002). The measurement of engagement and burnout: A two sample confirmatory factor analytic approach. Journal of Happiness studies, 3(1), 71-92.

Schlager, T., Bodderas, M., Maas, P., \& Luc Cachelin, J. (2011). The influence of the employer brand on employee attitudes relevant for service branding: an empirical investigation. Journal of Services Marketing, 25(7), 497-508.

Srivastava, P., \& Bhatnagar, J. (2010). Employer brand for talent acquisition: an exploration towards its measurement. Vision, 14(1-2), 25-34.

Tabak, F., \& Hendy, N. T. (2016). Work engagement: Trust as a mediator of the impact of organizational job embeddedness and perceived organizational support. Organization Management Journal, 13(1), 21-31.

Tian, A. W., Cordery, J., \& Gamble, J. (2016). Staying and performing: How human resource management practices increase job embeddedness and performance. Personnel Review, 45(5), 947-968.

Tremblay, M., Cloutier, J., Simard, G., Chênevert, D., \& Vandenberghe, C. (2010). The role of HRM practices, procedural justice, organizational support and trust in organizational commitment and in-role and extra-role performance. The International Journal of Human Resource Management, 21(3), 405-433.

Unit, E. I. (2008). Talent Wars: The Struggle for Tomorrow's Workforce.

Wayne, S. J., Shore, L. M., \& Liden, R. C. (1997). Perceived organizational support and leader-member exchange: A social exchange perspective. Academy of Management journal, 40(1), 82-111.

Wilden, R., Gudergan, S., \& Lings, I. (2010). Employer branding: strategic implications for staff recruitment. Journal of Marketing Management, 26(1-2), 56-73.

Zhang, Y., Farh, J. L., \& Wang, H. (2012). Organizational antecedents of employee perceived organizational support in China: a grounded investigation. The International Journal of Human Resource Management, 23(2), 422-446. 